\title{
Denitrification and Availability of Carbon and Nitrogen in a Well-drained Pasture Soil Amended with Particulate Organic Carbon
}

\author{
Bryan A. Stevenson,* Louis A. Schipper, Alexandra McGill, and Dave Clark
}

A well-drained soil in $\mathrm{N}$-fertilized dairy pasture was amended with particulate organic carbon (POC), either sawdust or coarse woody mulch, and sampled every 4 wk for a year to test the hypothesis that the addition of POC would increase denitrification activity by increasing the number of microsites where denitrification occurred. Overall mean denitrifying enzyme activity (DEA), on a gravimetric basis, was $100 \%$ greater for the woody mulch treatment and $50 \%$ greater for the sawdust treatment compared with controls, indicating the denitrifying potential of the soil was enhanced. Despite differences in DEA, no difference in denitrification rate, as measured by the acetylene block technique, was detected among treatments, with an average annual $\mathrm{N}$ loss of $-22 \mathrm{~kg} \mathrm{~N}$ $\mathrm{ha}^{-1} \mathrm{yr}^{-1}$. Soil water content overall was driving denitrification in this well-drained soil as regression of the natural log of volumetric soil water content (VWC) against denitrification rate was highly significant $\left(r^{2}=0.74, P<0.001\right)$. Addition of the amendments, however, had significant effects on the availability of both $\mathrm{C}$ and $\mathrm{N}$. An additional 20 to $40 \mathrm{~kg} \mathrm{~N}$ $\mathrm{ha}^{-1}$ was stored in POC-amended treatments as a result of increases in the microbial biomass. Basal respiration, as a measure of available C, was $400 \%$ greater than controls in the sawdust treatment and $250 \%$ greater than controls in the mulch. Net $\mathrm{N}$ mineralization, however, was significantly lower in the sawdust treatment, resulting in significantly lower nitrate $\mathrm{N}$ levels than in the control. We attribute the lack of measured response in denitrification rate to the high temporal variability in denitrification and suggest that diffusion of nitrate may ultimately have limited denitrification in the amended treatments. Our data indicate that manipulation of denitrification by addition of POC may be possible, particularly when nitrate levels are high, but quantifying differences in the rate of denitrification is difficult because of the temporal nature of the process (particularly the complex interaction of $\mathrm{N}$ availability and soil water content).
Copyright $\odot 2011$ by the American Society of Agronomy, Crop Science Society of America, and Soil Science Society of America. All rights reserved. No part of this periodical may be reproduced or transmitted in any form or by any means, electronic or mechanical, including photocopying, recording, or any information storage and retrieval system, without permission in writing from the publisher.

J. Environ. Qual. 40:923-930 (2011)

doi:10.2134/jeq2010.0463

Posted online 24 Mar. 2011.

Received 23 Oct. 2010.

*Corresponding author (stevensonb@landcareresearch.co.nz).

(c) ASA, CSSA, SSSA

5585 Guilford Rd., Madison, WI 53711 USA
$\mathrm{D}$ ENITRIFICATION, the microbial process in which nitrate is used as an electron acceptor in the absence of oxygen $\left(\mathrm{O}_{2}\right)$, is the main avenue by which reactive $\mathrm{N}$ can be converted back to inert atmospheric dinitrogen $\left(\mathrm{N}_{2}\right)$, though incomplete denitrification can result in production of the greenhouse gas nitrous oxide $\left(\mathrm{N}_{2} \mathrm{O}\right)$. Efforts are increasingly being made to manipulate the process to control excess $\mathrm{N}$ leaching to surface and ground waters. Denitrification walls or beds, submerged permeable bioreactor units filled with organic $\mathrm{C}$ substrates, where $\mathrm{N}$ rich water is denitrified as it flows through, have shown promise (Schipper et al., 2010). Evidence that denitrification can be manipulated in soil, before nitrate is leached to groundwater, however, is lacking. A few studies have shown that denitrification activity can be affected by soil water content during irrigation (for instance, Lowrance et al., 1998; Sparling et al., 2001). Additionally, Schipper and McGill (2008) constructed a layer of wood chips below the topsoil in dairy pasture irrigated with effluent in an effort to reduce nitrate leaching. They measured increased denitrifying enzyme activity (DEA) but did not observe reduced $\mathrm{N}$ leaching, primarily because organic $\mathrm{N}$ and ammonium $\mathrm{N}$ were mobilized from the layer.

Availability of $\mathrm{O}_{2}$, nitrate, and $\mathrm{C}$ (referred to as proximal factors) control denitrification rates at a field scale, but distal factors such as climatic and soil characteristics that control proximal factors can become important on broader scales (Groffman et al., 1987). Proximal factors are generally considered to be more important than the composition of the microbial community because a variety of microbes are capable of facultative anaerobic denitrification (Groffman et al., 1987; Tiedje, 1989), but Wallenstein et al. (2006a) suggest that distal factors shape the microbial community and thus microbial community composition can indirectly affect denitrification activity.

In most managed, nonirrigated systems, the availability of $\mathrm{O}_{2}$, which in turn is controlled by soil moisture content, has generally been considered the limiting environmental factor (Smith and Tiedje, 1979; Mosier et al., 1986). Water-filled pore space (WFPS) is often used to assess the relationship between soil moisture and denitrification rate. Minimum WFPS values for denitrification are generally between 50 and $80 \%$, with fine-textured soils having the smaller values and coarse-textured soils the larger

B.A. Stevenson and A. McGill, Landcare Research Ltd. Private Bag 3127, Hamilton, New Zealand. L.A. Schipper, Dep. of Earth and Ocean Sciences, Univ. of Waikato, Hamilton, New Zealand; D. Clark, DairyNZ, Private Bag 322, Hamilton, New Zealand. Assigned to Associate Editor Philippe Vidon.

Abbreviations: DEA, denitrifying enzyme activity; LMM, linear mixed model; POC, particulate organic carbon; REML, restricted maximum likelihood; VWC, volumetric water content; WFPS, water-filled pore space. 
(Barton et al., 1999). Recently, van der Weerden et al. (2010) suggested that volumetric water content (VWC), rather than WFPS, better modeled $\mathrm{N}_{2} \mathrm{O}$ production in soils varying in bulk density (and therefore pore size distribution), as the larger pore sizes drain quickly and would not be expected to become anaerobic in free-draining soils.

Available nitrate is required to act as an electron acceptor for microbial oxidation of C. Reported nitrate threshold levels for denitrification are relatively low, 2 to $5 \mathrm{mg} \mathrm{kg}^{-1}$ (Ryden, 1983; Barton et al., 1999), but Ryden and Lund (1980) reported values as high as 10 to $20 \mathrm{mg} \mathrm{kg}^{-1}$ for a loam soil. Under soils with high $\mathrm{C}$ availability, it has been suggested that denitrification can be limited by nitrate, even in fertilized soils (Jordan, 1989; Colbourn, 1993). Additionally, Luo et al. (1999) added nitrate $\mathrm{N}$ to saturated cores in a New Zealand pasture soil and observed an increased denitrification rate regardless of season, concluding that diffusivity of nitrate in the soil may limit denitrification more than nitrate levels themselves.

The nature and quality of $\mathrm{C}$ substrate in bioreactors can affect efficiency of nitrate removal by denitrification with lower, more labile $\mathrm{C}$ material generally having greater efficiency than high C:N material (Greenan et al., 2006; Cameron and Schipper, 2010). Parkin (1987) suggested that in well-drained, nonirrigated soils, denitrification is primarily dependent on soil microsites that are anaerobic and that particulate organic carbon (POC) may act to create an environment for anaerobic microsites. Although incorporation of organic $\mathrm{C}$ material into agricultural soils has been studied to attenuate $\mathrm{N}$ leaching (De Neve et al., 2004; Chaves et al., 2005), little work has been done on the effects of POC amendments on denitrification in soil.

We hypothesized that the addition of POC, either sawdust or a coarse, woody mulch, mixed into a well-drained soil under dairying where nitrate levels are typically high, would increase denitrification by increasing the number of denitrifying microsites in the soil. A secondary objective of the study was to quantify annual denitrification rates for this dairy soil as denitrification rates are arguably the least quantified aspect of the $\mathrm{N}$ cycle in many systems.

Denitrification activity was measured every 4 wk for 12 mo by the acetylene block technique and DEA. The acetylene block technique is a measure of denitrification rate under existing conditions. It is generally considered a conservative measure and may underestimate denitrification in systems where $\mathrm{N}$ is limiting, but it is still used in agricultural soils where $\mathrm{N}$ is generally in surplus (Groffman et al., 2006). The DEA is a measure of the activity of pre-existing denitrifying enzymes in the soil when not constrained by limitations of $\mathrm{C}$, nitrate, and anaerobic condition (Smith and Tiedje, 1979). This measure has been shown to correlate to denitrification rate and has been used as both a measure of potential denitrification rate and a longer term indicator of denitrifying activity (Tiedje, 1994; Groffman et al., 2006; Smith \& Tiedje, 1979; Tiedje, 1994). Additionally, soil nitrate, $\mathrm{pH}$, basal respiration, microbial biomass $\mathrm{C}$ and $\mathrm{N}$, and laboratory net $\mathrm{N}$ mineralization were measured to determine the effects of the amendments on microbial transformation of $\mathrm{C}$ and $\mathrm{N}$.

\section{Materials and Methods}

\section{Site and Experimental Design}

The study site was located on the DairyNZ Scott Farm in central Waikato of the North Island of New Zealand $\left(37^{\circ} 46^{\prime} 28^{\prime \prime} \mathrm{S}\right.$, $\left.175^{\circ} 21^{\prime} 33^{\prime \prime} \mathrm{E}\right)$. The region has a temperate climate with mean annual precipitation of $1250 \mathrm{~mm} \mathrm{yr}^{-1}$, mean summer temperature of $23.8^{\circ} \mathrm{C}$, and mean winter temperature of $13.6^{\circ} \mathrm{C}$. Summer (January-March) is generally the driest part of the year and droughty conditions often occur, but the maritime influence on climate can result in significant precipitation throughout the year. The soil was a well-drained Horotiu sandy loam (Typic Orthic Allophanic Soil, New Zealand classification; Vitric Hapludand, U.S. Soil Taxonomy). Pastures consisted of a rye grass (Lolium perenne L.)/white clover (Trifolium repens L.) mix. Dry matter production was $17.5 \mathrm{t} \mathrm{ha}^{-1} \mathrm{yr}^{-1}$, stocking rate was 3.0 cows ha ${ }^{-1}$, and the plots received $220 \mathrm{~kg} \mathrm{~N} \mathrm{ha}^{-1}$ in the form of urea during the study applied in split applications of $36.8 \mathrm{~kg} \mathrm{~N} \mathrm{ha}^{-1}$ on 24 April, 19 July, 9 September, 1 October, 17 October, and 1 December of 2008.

The study was set out in a randomized complete block design with five blocks and four treatment plots $(5 \mathrm{~m}$ by $5 \mathrm{~m})$ in each block. Treatments were initiated in September of 2007 and consisted of: (i) sawdust-amended treatment, (ii) coarse, woody, mulch-amended treatment, (iii) disturbed control to control the effects of soil disturbance associated with amended treatments, and (iv) undisturbed control. The sawdust was obtained from a Monterey pine (Pinus radiata) mill with particle size $<1 \mathrm{~mm}$ diam. The coarse, woody mulch was obtained from a local tree cutting service where woody material (bark, limbs, and trunks) had been put through a shredder. Though the material was generally coarser than the sawdust, size of particles varied considerably (from $<1 \mathrm{~mm}-10 \mathrm{~mm}$ ).

In the C-amended treatments, approximately $55 \mathrm{Mg} \mathrm{ha}^{-1}$ (dry wt.) of the amendment was rototilled into the A horizon of the soil to a depth of $15 \mathrm{~cm}$. For the disturbed control, soil was rototilled to a similar depth but no amendment was added. The undisturbed control consisted of plots where no disturbance to the pasture had occurred. The C-amended and disturbed-control plots were reseeded with a ryegrass/clover mix that matched surrounding pasture and then fenced off to restrict grazing until grass cover had reached $100 \%$. Fencing was removed and grazing was allowed on all plots for 2 mo before the initial sampling.

\section{Sampling and Analytical Procedures}

\section{Soil Characteristics}

Approximately $102-\mathrm{cm}$ by $10-\mathrm{cm}$ soil cores were collected every 4 wk beginning 1 Mar. 2008, from each plot and bulked to analyze for soil chemical and biological measurements. Total $\mathrm{C}$ and $\mathrm{N}$ were only analyzed for the initial sampling (March 2008), by dry combustion on air-dried, sieved $(<2 \mathrm{~mm})$, and finely ground soils using a 2000 CNS analyzer (Leco Corp., St. Joseph, MI). Soil $\mathrm{pH}$, soil nitrate $\mathrm{N}$, and basal respiration were measured every $4 \mathrm{wk}$ (total of 13 sampling dates) and followed the procedure outlined in Blakemore et al. (1987). In brief, soil $\mathrm{pH}$ was measured using a combination electrode from a 1:2.5 soil to water extract. Soil nitrate was measured on a $2 \mathrm{M} \mathrm{KCl}$ 
extract after shaking for $1 \mathrm{~h}$. Basal respiration rate was measured as the increase in headspace $\mathrm{CO}_{2}$ concentration during a $7-\mathrm{d}$ incubation at $25^{\circ} \mathrm{C}$ and field moisture content.

Microbial biomass $\mathrm{C}$ and $\mathrm{N}$, and total net $\mathrm{N}$ mineralization (56 d) were measured every 3 mo (total of five sampling dates). Microbial $\mathrm{C}$ and $\mathrm{N}$ were measured on field moist samples by using the fumigation-extraction procedure (Wu et al., 1990), with soil adjusted to $60 \%$ water-holding capacity. The k-factors used for converting extractable $\mathrm{C}$ and $\mathrm{N}$ flush to microbial $\mathrm{C}$ and $\mathrm{N}$ were respectively 0.41 (Sparling and Zhu, 1993) and 0.45 (Jenkinson, 1988). Net $\mathrm{N}$ mineralization was measured following the procedure of Scott et al. (1998) on freshly collected soils by subtracting final from initial $2 \mathrm{M} \mathrm{KCl}$ extractable soil ammonium and nitrate concentrations from soil incubated aerobically at $-5 \mathrm{kPa}$ moisture content for $56 \mathrm{~d}$ at $25^{\circ} \mathrm{C}$.

Soil water content was measured gravimetrically from the bulk samples collected every $4 \mathrm{wk}$ and converted to a volumetric basis using measured bulk density values (see below under denitrification measurements) for each plot. WFPS was calculated by the formula:

$\% \mathrm{WFPS}=100 \times \mathrm{VWC} /[1-(\mathrm{BD} / \mathrm{PD})]$

where VWC equals volumetric water content, BD equals soil bulk density, and PD equals soil particle density. A particle density of 2.32 was experimentally determined for the site during preliminary assessment of soil characteristics.

\section{DEA and Denitrification Rate}

The DEA was measured as described by Tiedje et al. (1989). Briefly, $10 \mathrm{~g}$ soil from the bulk soil samples, collected every 4 wk beginning 1 Mar. 2008, was incubated in 100-mL Schott bottles in the presence of $20 \mathrm{~mL}$ of glucose-nitrate solution $\left(0.2 \mathrm{~g}\right.$ glucose and $\left.0.1 \mathrm{~g} \mathrm{KNO}_{3} \mathrm{~L}^{-1}\right)$ and $0.125 \mathrm{~g}$ chloramphenicol L-1 (to prevent protein synthesis). The bottles were sealed and flushed for 2 min with $\mathrm{N}_{2}$ gas through septa fitted in the lids. Acetylene $(10 \mathrm{~mL})$ was added and the samples were incubated at $25^{\circ} \mathrm{C}$ on a rotary shaker. The $5 \mathrm{~mL}$ of headspace gas was removed at 15 and $75 \mathrm{~min}$, and placed into a $3-\mathrm{mL}$ Vacutainer tube for $\mathrm{N}_{2} \mathrm{O}$ determinations on a Phillips model PU4410 Gas Chromatograph (Koninklijke Philips Electronics, Lancashire, UK) with an electron capture detector.

Denitrification rate was measured by the acetylene block technique, using the static soil core incubation system as described by Ryden et al. (1987). Five soil cores (in addition to those taken for bulk soil analyses) were extracted from each plot every $4 \mathrm{wk}$ beginning 1 Mar. 2008. The $3.2-\mathrm{cm}$ diam. by $15-\mathrm{cm}$ depth cores were in perforated PVC liners that allowed gas exchange. The five cores from each plot were placed in a preserving jar fitted with a gas sampling septum in the lid and transported to the laboratory. Within $2 \mathrm{~h}$ of extraction from the soil, acetylene was added to the jars with a $60-\mathrm{mL}$ syringe and mixed with headspace air to obtain $10 \% \mathrm{v} / \mathrm{v}$. The jars were kept in a temperature-controlled room during incubation, which was set to the temperature of the soil at the time of collection. (3.2 cm diam. by $15 \mathrm{~cm}$ depth)

Headspace gas samples were taken from the jars at 0,3 , and $6 \mathrm{~h}$ after addition of acetylene and stored in Exetainer tubes under positive pressure until analysis. Samples beyond $6 \mathrm{~h}$ were not obtained, as previous experiments with this soil had shown that $\mathrm{N}_{2} \mathrm{O}$ production was generally not linear between 6 and $24 \mathrm{~h}$. Headspace gas samples were analyzed on a Shimadzu 17A gas chromatograph (Shimadzu Oceania Pty. Ltd., Nelson, New Zealand) with a Gilson 222XL autosampler (Gilson Inc., Middleton, WI), and electron capture detector. Hourly denitrification rates were calculated from the headspace concentration of $\mathrm{N}_{2} \mathrm{O}$ at each sampling time and corrected for the solubility of the $\mathrm{N}_{2} \mathrm{O}$ in the soil water using the Bunsen absorption coefficient (Tiedje, 1994). After completion of the analysis, soil was removed from the cores, oven dried at $105^{\circ} \mathrm{C}$, and the weight used to calculate bulk density of the soil from each treatment based on the volume of the cores.

\section{Statistical Analysis}

Data were analyzed on GenStat statistical software (Version 10.1, Lawes Agricultural Trust). Where appropriate, data were converted to an area basis (expressed on a per hectare basis to a $10-\mathrm{cm}$ depth for all measurements, except for denitrification rate, which was to a $15-\mathrm{cm}$ depth) for more valid comparison among treatments that may differ in bulk density. To evaluate treatment effects for variables measured at greater than monthly intervals (e.g., total and microbial biomass $\mathrm{C}$ and $\mathrm{N}$, and net $\mathrm{N}$ mineralization), data were averaged over all time periods and the overall means log transformed when necessary and analyzed by one-way ANOVA.

For variables measured every $4 \mathrm{wk}$, data were log transformed when necessary and analyzed by a restricted maximum likelihood (REML) linear mixed model (LMM) to assess both time and treatment effects. Time, treatment, and time $\times$ treatment were the fixed effects, and block $\times$ time $\times$ treatment the random effect. The REML approach was used over a univariate repeated measures ANOVA because treatment variance differentially varied over time. Nontransformed means and variances were shown in tables for easier interpretation of the results. Simple and multiple linear regression analyses were used to assess the relationship between measures of denitrification and other soil parameters. A forward, stepwise, multiple regression approach (selecting only parameters where $P<0.05$ ) was used to select the best fit regression model.

\section{Results}

\section{Soil Properties}

Mean values by treatment, averaged over all sampling periods, for soil properties are shown in Table 1. There were few significant differences in measured soil properties between the undisturbed and disturbed control treatments, indicating minimal effect of plot disturbance. Only microbial biomass $\mathrm{C}$ in the undisturbed control was greater than that in the disturbed control. Additionally, there was one instance (nitrate $\mathrm{N}$ ) where an amended treatment was significantly lower than the disturbed control but not the undisturbed control.

The POC amendments, however, resulted in a significant decrease in soil bulk density. Consequently, statistical significance among treatments for some measurements differed when expressed on a gravimetric versus area basis. Since gas flux measurements are generally presented on an area basis, for consistency we present all data in this manner. Where presentation of data on a gravimetric basis helps to elucidate trends or is 
Table 1. Mean values by treatment (averaged over all sampling periods) for soil properties. Measurements are to a $100 \mathrm{~mm}$ depth.

\begin{tabular}{|c|c|c|c|c|c|}
\hline \multirow{2}{*}{ Measurement } & \multirow{2}{*}{$\begin{array}{l}\text { Sampling } \\
\text { frequency }\end{array}$} & \multicolumn{4}{|c|}{ Treatment } \\
\hline & & Undisturbed control & Disturbed control & Sawdust & Woody mulch \\
\hline Total C (\% w/w) & March 2008 only & 7.99 (0.18)a & $7.76(0.34) a$ & $11.40(0.68) b$ & $10.23(0.29) \mathrm{b}$ \\
\hline Total C $\left(\mathrm{Mg} \mathrm{C} \mathrm{ha-1}^{-1}\right)$ & & 70.3 (1.9)a & $65.0(2.0) \mathrm{a}$ & $72.9(4.8) \mathrm{a}$ & $72.9(3.4) \mathrm{a}$ \\
\hline Total N (\% w/w) & & $0.74(0.01) a$ & $0.72(0.03) a$ & $0.72(0.02) a$ & $0.85(0.03) b$ \\
\hline Total N $\left(\mathrm{Mg} \mathrm{N} \mathrm{ha}^{-1}\right)$ & & $6.52(0.16) b$ & $6.04(0.17) b$ & $4.63(0.14) a$ & $6.07(0.32) b$ \\
\hline $\mathrm{C}: \mathrm{N}$ & & $10.8(0.2) \mathrm{a}$ & $10.8(0.2) \mathrm{a}$ & $15.8(1.2) b$ & $12.0(0.3) \mathrm{a}$ \\
\hline Microbial biomass $\mathrm{C}(\mathrm{kg} \mathrm{C} \mathrm{ha-1})$ & Every 3 mo & $888(27) b$ & $768(45) a$ & $1088(34) c$ & $1194(17) c$ \\
\hline Microbial biomass N (kg N ha-1) & & $102(7) a$ & $89(8) a$ & $125(3) b$ & $142(3) b$ \\
\hline 56-Day $\mathrm{N}$ mineralization $\left(\mathrm{kg} \mathrm{N} \mathrm{ha}^{-1}\right)$ & & $126(17) \mathrm{b}$ & $126(14) \mathrm{b}$ & $13(13) \mathrm{a}$ & $111(17) b$ \\
\hline Basal respiration $\left(\mathrm{kg} \mathrm{C} \mathrm{ha-1}^{-1} \mathrm{~h}^{-1}\right)$ & Every 4 wk & $2.11(0.10) a$ & $1.82(0.17) a$ & $8.05(0.34) c$ & $5.19(0.23) b$ \\
\hline Nitrate-N (kg N ha $\left.{ }^{-1}\right)$ & & $18.4(5.6) b c$ & $27.1(6.2) c$ & $7.7(2.3) a$ & $10.7(1.4) a b$ \\
\hline $\mathrm{pH}$ & & $5.87(0.10) a$ & $5.79(0.13) a$ & $5.80(0.08) a$ & $6.17(0.06) b$ \\
\hline Soil moisture (\% w/w) & & 52.5 (3.0)ab & $53.5(1.2) \mathrm{a}$ & $62.5(1.5) b$ & $60.8(1.5) b$ \\
\hline Soil moisture (\% v/v) & & $41.3(0.9) a$ & $42.2(0.4) a$ & 40.7 (0.7)a & $41.1(0.5) \mathrm{a}$ \\
\hline WFPS (\%) & & $63.2(0.8) b$ & $64.2(0.7) b$ & $56.8(1.2) \mathrm{a}$ & $58.2(0.7) a$ \\
\hline Bulk density $\left(\mathrm{g} \mathrm{cm}^{-3}\right)$ & & $0.81(0.03) b$ & $0.80(0.01) b$ & $0.66(0.01) a$ & $0.69(0.01) a$ \\
\hline
\end{tabular}

† Numbers in parentheses are one standard error of the mean. Differing letters within each row represent statistically significant differences among treatments $(P<0.05)$.

intuitively more comprehensible, we also present the gravimetric measurement.

Both the sawdust and woody mulch amendments increased total C (on a gravimetric basis) in comparison with controls. Because of the differences in bulk density, however, there was no difference in total $\mathrm{C}$ among treatments on an area basis. Mean microbial biomass $\mathrm{C}$ was also significantly greater in both amended treatments in comparison with controls, approximately a quarter to a third greater, and was lower in the disturbed control than the undisturbed control.

Time and treatment effects were significant $(P<0.001)$ for basal respiration. Both $\mathrm{C}$ amendments significantly increased basal respiration rates with the sawdust treatment having the larger increase, approximately $400 \%$, and the mulch treatment approximately $250 \%$ greater than controls. The time $\times$ treatment effect was also all significant $(P=0.02)$. Respiration values were greater during the wet, winter months and the relative difference among amended treatments and control treatments generally greater during these months (Fig. 1).

In contrast to soil $\mathrm{C}$, changes in $\mathrm{N}$ status of the soil were much more dependent on the type of amendment added. On a gravimetric basis, the mulch treatment increased the total $\mathrm{N}$ content of the soil, but the sawdust addition did not. Consequently, there was a significant increase in soil $\mathrm{C} / \mathrm{N}$ for the sawdust treatment compared with controls but no significant change for the woody mulch treatment (Table 1). On an area basis, mean total $\mathrm{N}$ was lower in the sawdust treatment than the controls and mulch treatment. There was no difference in microbial biomass $\mathrm{N}$ between amended treatments, but both amended treatments were greater than controls. However, in contrast to microbial biomass $\mathrm{C}$, there was no significant difference between controls. The 56-d net $\mathrm{N}$ mineralization was significantly reduced in the sawdust treatment in comparison with controls, but the mulch amendment was similar to controls.

Soil nitrate-N was highly variable (Fig. 1), but both treatment and time effects were significant $(P<0.001)$. Mean nitrate- $\mathrm{N}$ was significantly lower in the sawdust treatment compared with the controls (Table 1), but the woody mulch treatment was intermediate between the sawdust and undisturbed control, and only significantly lower than the disturbed control. There was also a small but significant increase in soil $\mathrm{pH}$ in the mulch-amended treatment compared with control and sawdust-amended treatments.

Gravimetric soil water content was greater in C-amended treatments (Table 1), but because of the decrease in bulk density and concurrent increase in total porosity, there was no overall difference in VWC among treatments (Fig. 1). Both time and time $\times$ treatment effects were significant $(P<0.001)$ for VWC. Treatment, time, and time $\times$ treatment effects were all significant for WFPS $(P<0.001)$, as overall mean values were significantly lower in amended plots than control plots (Table 1).

\section{DEA and Denitrification Rate}

Since DEA represents a measure of potential denitrification, gravimetric, as well as area measurements, are presented to better gauge the effect of the amendments on denitrification activity. On a gravimetric basis, time and treatment effects were significant $(P<0.001)$, as was the treatment $\times$ time interaction $(P=0.002)$. The overall mean DEA for both amended treatments was significantly greater than control treatmentsapproximately $100 \%$ greater for the mulch treatment and 50\% greater for the sawdust treatment (Table 2). When considered on an area basis, all effects were still significant $(P<0.001$ for time and $P<0.005$ for treatment and time $\times$ treatment), but only DEA on the woody mulch treatment was significantly greater than controls. The DEA varied irregularly throughout the year (Fig. 2), but there was a large increase in DEA for both amended treatments in May.

For denitrification rate by the acetylene block method, treatment was not significant, but time and time $\times$ treatment effects were significant $(P<0.001)$. Denitrification rate was generally higher in winter and spring months of August through November (Fig. 2), but there appeared to be no seasonal pattern where particular treatments were greater than 


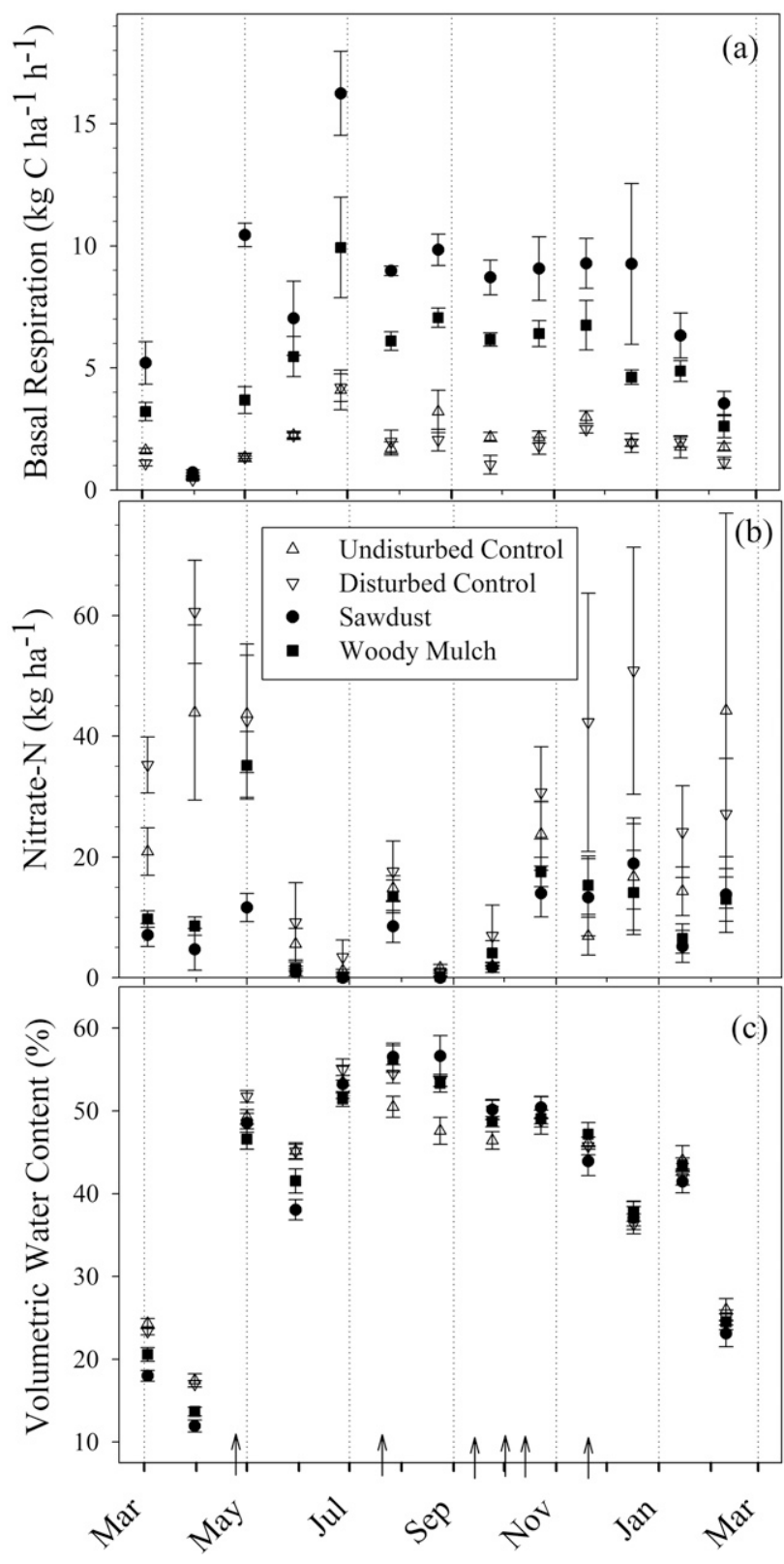

Fig. 1. Mean values by treatment $(n=5)$ over time for soil factors that affect denitrification (a) basal respiration, (b) soil nitrate $\mathrm{N}$, and (c) volumetric soil water content beginning March 2008. Error bars represent one standard error of the mean. Arrows on the $\mathrm{X}$ axis indicate dates of urea application where $36.8 \mathrm{~kg} \mathrm{~N} \mathrm{ha}^{-1}$ were applied per application.

others. Cumulative denitrification rate varied little among treatments (ranging from $-21-22 \mathrm{~kg} \mathrm{~N} \mathrm{ha}^{-1} \mathrm{yr}^{-1}$ ) and averaged $21.7 \mathrm{~kg} \mathrm{~N} \mathrm{ha}^{-1} \mathrm{yr}^{-1}$ over all treatments (Table 2). Cumulative rates for individual plots, however, varied between 10 and 60 $\mathrm{kg} \mathrm{N} \mathrm{ha}{ }^{-1} \mathrm{yr}^{-1}$, underscoring the large spatial variability for denitrification.

The ratio of denitrification rate to DEA (as a measure of actual to potential denitrification) was highly variable (Table 2 ). The treatment effect was not significant (though marginally so at $P=0.06)$, but time $(P<0.001)$ was a significant effect. Denitrifying enzyme activity was generally several orders of magnitude greater than denitrification. Maximum values in the ratio (0.01) occurred in August to late September and minimum values $(<0.0001)$ occurred in February.

Simple regression of VWC against the natural log of denitrification rate explained $74 \%$ (versus $69 \%$ for WFPS) of the variance in denitrification over the year. Since VWC was most correlated to denitrification rate, it was used as the measure of soil water content in multiple regression analyses. A forward, stepwise, multiple regression model of VWC, log nitrate N, $\log$ basal, $\mathrm{pH}$, and treatment significantly decreased the error of the residuals and explained $79 \%$ of the total variation. Examination of the treatment effect indicated that slope was not significantly different, but the intercept for the sawdust treatment was greater than that of control treatments. The intercept for the mulch treatment was not significantly greater than controls.

Log basal was the single variable that was most significant in regression against DEA, but it only explained $18 \%$ of the total variance. Multiple regression yielded an $R^{2}$ of 0.34 , using VWC, log-nitrate $\mathrm{N}$, and treatment, but residuals plotted against predicted values suggested a quadratic equation might best fit the data. The stepwise regression model rerun with the addition of squared terms selected a model of $\mathrm{VWC}^{2}$, VWC, $\log$ basal, and treatment, which explained $55 \%$ of the total variance. Examination of the treatment effect indicated that slopes did not differ among treatments, but the intercepts for both the sawdust and mulch treatments were significantly greater than those of control treatments.

\section{Discussion}

\section{Denitrification Rate}

Neither addition of sawdust nor mulch had significant impact on denitrification rate as measured by the acetylene block technique. The cumulative denitrification rate across all treatments of $22 \mathrm{~kg} \mathrm{~N} \mathrm{ha}^{-1} \mathrm{yr}^{-1}$ in this pastoral system was slightly above the mean of approximately $13 \mathrm{~kg} \mathrm{~N} \mathrm{ha}^{-1} \mathrm{yr}^{-1}$ reported by Barton et al. (1999) for fertilized, nonirrigated, agricultural systems. The regression analyses indicated that over the course

Table 2. Mean values by treatment (averaged over all sampling periods) for denitrification activity. Measurements were made every 4 wk from March 2008 to February 2009 and are to a 10-cm depth for denitrifying enzyme activity (DEA) and 15-cm depth for denitrification rate.

\begin{tabular}{|c|c|c|c|c|}
\hline \multirow{2}{*}{ Measurement } & \multicolumn{4}{|c|}{ Treatment } \\
\hline & Undisturbed control & Disturbed control & Sawdust & Woody mulch \\
\hline $\mathrm{DEA}\left(\mathrm{mg} \mathrm{N}_{2} \mathrm{O}-\mathrm{N} \mathrm{kg} \mathrm{soil}{ }^{-1} \mathrm{~h}^{-1}\right)$ & $1.41(0.31) a \dagger$ & $1.33(0.27) a$ & $2.10(0.39) \mathrm{b}$ & $3.03(0.50) c$ \\
\hline DEA $\left(\mathrm{kg} \mathrm{N}_{2} \mathrm{O}-\mathrm{N} \mathrm{ha}^{-1} \mathrm{~h}^{-1}\right)$ & $1.09(0.23) \mathrm{a}$ & $1.04(0.20) \mathrm{a}$ & $1.36(0.25) \mathrm{a}$ & $2.03(0.33) b$ \\
\hline Denitrification rate $\left(\times 10^{-3} \mathrm{~kg} \mathrm{~N}_{2} \mathrm{O}-\mathrm{N} \mathrm{ha}^{-1} \mathrm{~h}^{-1}\right)$ & $2.47(0.79) a$ & $2.48(0.71) a$ & $2.60(0.95) a$ & $2.38(0.67) \mathrm{a}$ \\
\hline Cumulative denitrification $\left(\mathrm{kg} \mathrm{N}_{2} \mathrm{O}-\mathrm{N} \mathrm{ha}^{-1} \mathrm{yr}^{-1}\right.$ ) & $21.6(5.9) \mathrm{a}$ & 21.7 (3.6)a & 22.7 (9.7)a & 20.7 (3.3)a \\
\hline Denitrification rate to DEA Ratio $\left(\times 10^{-3}\right)$ & $2.53(1.13) a$ & $2.49(1.03) a$ & $3.48(1.45) a$ & $0.83(0.28) a$ \\
\hline
\end{tabular}

† Numbers in parentheses are one standard error of the mean. Differing letters within each row represent statistically significant differences among treatments $(P<0.05)$. 


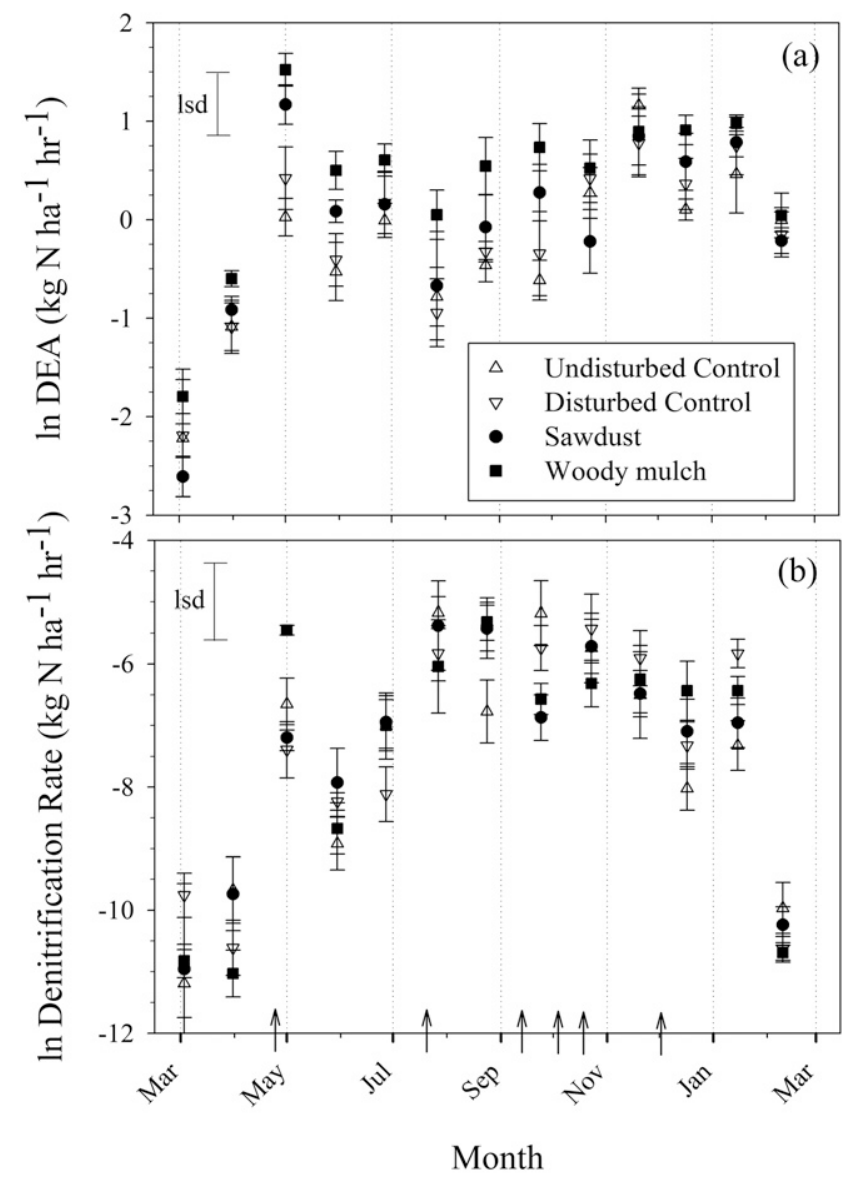

Fig. 2. Mean transformed values by treatment $(n=5)$ for measures of denitrification activity (a) denitrifying enzyme activity (DEA) and (b) denitrification rate by acetylene block, beginning March 2008. Error bars represent one standard error of the mean. The least significant difference for same treatment means over time is indicated in the upper left corner and the difference among treatments means within one time was similar. Arrows on the $\mathrm{X}$ axis indicate dates of urea application where $36.8 \mathrm{~kg} \mathrm{~N} \mathrm{ha}^{-1}$ were applied per application.

of the year, soil water content was the variable most controlling denitrification rate. Regression lines did not significantly differ among treatments in the simple regression, indicating no differential effect of soil water content on denitrification rate. The $r^{2}$ value of 0.74 for VWC is relatively high in comparison with other studies (Barton et al., 1999). But given that soil moisture level and/or soil texture as proxies for oxygen availability have often explained a large proportion of variance in denitrification, we would expect soil water content to be driving denitrification in this well-drained soil as water content can vary dramatically even within season.

Nitrate-N, basal respiration, and treatment effects were also significant in the multiple regression model but explained only a relatively small additional amount of the variance. This also agrees with our understanding of the denitrification process, as differences in available $\mathrm{C}$ and nitrate among treatments will only become important when anaerobic conditions occur. The strong correlation of VWC to denitrification rate suggests that although basal respiration rate, and therefore $\mathrm{O}_{2}$ consumption, was clearly greater in the amended treatments, there was little evidence that the amendments appreciably changed the anaerobic status of this well-drained soil over seasonal time frames. Both the significant treatment term in the multiple regression model and the significant time $\times$ treatment interaction in the LMM, however, indicate that there was a differential response in denitrification among treatments over time. We explore these differences in relation to DEA in the remainder of the discussion section.

\section{DEA}

The increase in DEA on a gravimetric basis compared with the control treatments indicated that addition of both forms of POC, but particularly the mulch, enhanced the potential denitrifying ability of the soil. The associated change in bulk density largely negated the increase in DEA for the sawdust treatment on an area basis, but DEA was still significantly greater than controls for the mulch treatment. Most studies conducted in the field have related DEA to differences in soil aeration or moisture content (Groffman and Tiedje, 1989; Parsons et al., 1991; Barton et al., 2000). But supply of available C (Bijay-Singh et al., 1988) and addition of sawdust or woodchips to saturated soil (Schipper and Vojvodić-Vuković, 1998; Schipper and McGill, 2008) have also been shown to increase DEA. In our experiment, there was no significant difference in water content between the two POC-amended treatments, although it is possible that pore size distribution differed. Microbial biomass was also similar between the amended treatments, but the sawdust treatment had greater basal respiration (as a measure of available $\mathrm{C}$ ) than the mulch treatment, and yet DEA was lower.

The major difference between the sawdust and mulch treatments was their effect on $\mathrm{N}$ status of the soil. The mulch addition increased total $\mathrm{N}$ (as well as total $\mathrm{C}$ ), resulting in no significant change to the $\mathrm{C}: \mathrm{N}$ ratio, whereas the sawdust treatment resulted in a significant increase to the soil C:N ratio. Both POC-amended treatments contained large amounts of $\mathrm{N}$ in microbial biomass (between 20 and $40 \mathrm{~kg} \mathrm{~N} \mathrm{ha}^{-1}$ greater than control treatments), but $\mathrm{N}$ mineralization was significantly lower in the sawdust treatment than in the mulch and control treatments. Nitrate- $\mathrm{N}$ in the sawdust treatment was also significantly lower than the undisturbed control, whereas nitrate- $\mathrm{N}$ in the mulch treatment was not.

The ability of organic substrates to immobilize $\mathrm{N}$ in cropping systems differs (De Neve et al., 2004; Chaves et al., 2007) and we think it likely the sawdust was still immobilizing a significant amount of $\mathrm{N}$ and DEA in the sawdust treatment was limited by too little available nitrate. To further support this contention, there was a large increase in DEA for the sawdust and mulch treatments in May-just after a urea application (Fig. 2).

There was a significant difference in $\mathrm{pH}$ between the amended treatments, as the mulch raised soil $\mathrm{pH}$ from about 5.8 to 6.2. Changes in $\mathrm{pH}$ can affect both total denitrification rate and the ratio of $\mathrm{N}_{2}: \mathrm{N}_{2} \mathrm{O}$ emitted (Stevens et al., 1998), but data from Wallenstein et al. (2006b) at a lower $\mathrm{pH}$ forest site suggested this magnitude of change in $\mathrm{pH}$ did not greatly affect DEA. Additionally, comparison of soils differing in $\mathrm{pH}$ by Simek et al. (2002) suggested that DEA was generally greatest near the soil's natural $\mathrm{pH}$, so we think it unlikely that $\mathrm{pH}$ was a significant factor in explaining the differences in DEA. 


\section{Treatment Effects for DEA versus Denitrification Rate}

The question remains why the increase in DEA, particularly for the mulch treatment, did not translate into a greater denitrification rate. Soil water content overall was driving denitrification rate, but even during periods of high VWC, there was no discernible trend of higher denitrification rate in the mulch-amended treatment (Fig. 2). Though DEA in the mulch treatment was greater than that in the sawdust treatment, the multiple regression for denitrification rate showed that the intercept for the sawdust treatment was significantly higher than other treatments, indicating that all other factors being equal (VWC, nitrate $\mathrm{N}$, basal respiration, and $\mathrm{pH}$ ), the sawdust treatment would have the greatest denitrification rate. These factors suggest that either our sampling regime was not sufficient to detect differences in denitrification rate among treatments or there was a significant interaction among the proximal factors that differed by treatment and was limiting the denitrification rate. We suggest that a combination of both these possibilities were likely. Denitrification rate can be comparatively high for short periods of time - on the order of hours to days (e.g., "hot moments")—when conditions are optimal (Groffman et al., 2009), and it is probable that our monthly sampling missed many of these hot-moment events.

Wallenstein et al. (2006a) suggested that denitrifier community composition is structured by distal controls that act as a transducer through which proximal controls act to affect the rate and kinetics of denitrification. Our study, in effect, manipulated what Wallenstein et al. (2006a) considered a distal control—quantity and quality of soil C (e.g., C substrate availability) — which had effects on microbial biomass and, in turn, impacted $\mathrm{C}$ and nitrate availability. The degree to which these factors were altered, particularly for nitrate, was dependent on the amendment.

There is evidence that in soils with high $\mathrm{C}$ availability, denitrification can be limited by nitrate, even in fertilized soils (Jordan, 1989; Colbourn, 1993). Additionally, Luo et al. (1999) showed that diffusion of nitrate may limit denitrification more than nitrate levels themselves.

We suggest that the diffusion of nitrate was probably limiting denitrification rate during periods of high water content in the amended treatments. Nitrogen limitation for the sawdust treatment has been discussed in regard to DEA and it seems plausible that nitrate availability was both limiting the potential for greater denitrification to occur and actual denitrification rate during periods of high soil water content, particularly since nitrate $\mathrm{N}$ levels were significantly lower in the sawdust treatment than the undisturbed control. The evidence for $\mathrm{N}$ limitation in the mulch treatment was admittedly more circumstantial.

Nitrate-N levels in April for control treatments were elevated most likely due to an autumn drought that had limited plant uptake of $\mathrm{N}$. There was no increase in nitrate- $\mathrm{N}$ in amended treatments in April, as apparently they were able to immobilize this $\mathrm{N}$ into microbial biomass. Nitrate- $\mathrm{N}$ levels did increase in May for the mulch treatment $\left(-45 \mathrm{~kg} \mathrm{~N} \mathrm{ha}^{-1}\right.$ for the mulch-amended plot compared with about $55 \mathrm{~kg} \mathrm{~N} \mathrm{ha}^{-1}$ for control treatments), just after a urea application, but remained low in the sawdust treatment $\left(10 \mathrm{~kg} \mathrm{~N} \mathrm{ha}^{-1}\right)$. There was signifi- cant precipitation before the May sampling and denitrification rates were generally higher for all treatments but particularly so for the mulch treatment. Nitrate limitation would explain the large response in the denitrification rate in May for the mulch treatment, as DEA was high and there was also available nitrate. There was less response from the sawdust treatment as, although DEA had increased (either from the extra $\mathrm{N}$ in the urea application itself or there may have been a hot-moment event earlier in the month when precipitation first occurred), nitrate- $\mathrm{N}$ was still relatively low at the time of the denitrification measurement.

In summary, we attribute the lack of measured response in denitrification rate to the high temporal variability in denitrification and suggest that the diffusion of nitrate may have ultimately limited denitrification in the amended treatments. Though soil water content overall was driving the denitrification rate in this well-drained soil, the addition of the $\mathrm{C}$ substrates increased microbial biomass, which, in turn, had contrasting effects on $\mathrm{C}$ availability and nitrate. While direct manipulation of soil water content is likely to have greater effect on annual denitrification rates in well-drained soils on an annual basis, our data suggest that it may be possible to alter denitrification activity by addition of POC, particularly when soil nitrate levels are high and susceptible to leaching losses. Intensive measurement of denitrification rates is needed, however, to quantify differences due to the high temporal variability of the process, in particular, the availability of nitrate during periods of high soil water content,.

\section{Acknowledgments}

The research was funded through the Sustaining Soil Services Research grant (C09X0705) and supported by the New Zealand Foundation for Research Science and Technology. Roger Parfitt and two anonymous reviewers are thanked for comments on the manuscript.

\section{References}

Barton, L., C.D.A. McLay, L.A. Schipper, and C.T. Smith. 1999. Annual rates of denitrification in agricultural and forest soils: A review. Aust. J. Soil Res. 37:1073-1093. doi:10.1071/SR99009

Barton, L., L.A. Schipper, C.T. Smith, and C.D.A. McLay. 2000. Denitrification enzyme activity is limited by soil aeration in a wastewater-irrigated forest soil. Biol. Fertil. Soils 32:385-389. doi:10.1007/s003740000267

Bijay-Singh, J.C. Ryden, and D.C. Whitehead. 1988. Some relationships between denitrification potential and fractions of organic carbon in airdried and field-moist soils. Soil Biol. Biochem. 20:737-741.

Blakemore, L.C., P.L. Searle, and B.K. Daly. 1987. Methods for chemical analysis of soil. New Zealand Soil Bureau Scientific Rep. 80. New Zealand Soil Bureau, Wellington, New Zealand.

Cameron, S.G., and L.A. Schipper. 2010. Nitrate removal and hydraulic performance of organic carbon for use in denitrification beds. Ecol. Eng. 36:1588-1595.

Chaves, B., S. De Neve, P. Boeckx, O. Van Cleemput, and G. Hofman. 2005. Screening organic biological wastes for their potential to manipulate the $\mathrm{N}$ release from $\mathrm{N}$-rich vegetable crop residues in soil. Agric. Ecosyst. Environ. 111:81-92. doi:10.1016/j.agee.2005.03.018

Chaves, B., S. De Neve, L.M. Piulates, P. Boeckx, O. Van Cleemput, and G. Hofman. 2007. Manipulating the $\mathrm{N}$ release from $\mathrm{N}$-rich crop residues by using organic wastes on soil with different textures. Soil Use Manage. 23:212-219. doi:10.1111/j.1475-2743.2006.00063.x

Colbourn, P. 1993. Limits to denitrification in two pasture soils in a temperate maritime climate. Agric. Ecosyst. Environ. 43:49-68.

De Neve, S., S. Gaona Sa'ez, B. Chaves Daguilar, S. Sleutel, and G. Hofman. 2004. Manipulating $\mathrm{N}$ mineralization from high $\mathrm{N}$ crop residues using on- and off-farm organic materials. Soil Biol. Biochem. 36:127-134. doi: $10.1016 /$ j.soilbio.2003.08.023 
Greenan, C.M., T.B. Moorman, T.C. Kaspar, T.B. Parkin, and D.B. Jaynes. 2006. Comparing carbon substrates for denitrification of subsurface drainage water. J. Environ. Qual. 35:824-829. doi:10.2134/ jeq2005.0247

Groffman, P.M., M.A. Altabet, J.K. Bohlke, K. Butterbach-Bahl, M.D. David, M.K. Firestone, A.E. Giblin, T.M. Kana, L.P. Nielsen, and M.A. Voytek. 2006. Methods for measuring denitrification: Diverse approaches to a difficult problem. Ecol. Appl. 16:2091-2122. doi:10.1890/1051-0761(2006)016[2091:MFMDDA]2.0.CO;2

Groffman, P.M., K. Butterbach-Bahl, R.W. Fulwieler, A.J. Gold, J.L. Morse, E.K. Stander, C. Tague, C. Tonitto, and P. Vidon. 2009. Challenges to incorporating spatially and temporally explicit phenomena (hotspots and hot moments) in denitrification models. Biogeochemistry 93:49-77. doi:10.1007/s10533-008-9277-5

Groffman, P.M., and J.M. Tiedje. 1989. Denitrification in North temperate forest soils: Spatial and temporal patterns. Soil Biol. Biochem. 21:613-620.

Groffman, P.M., J.M. Tiedje, G.P. Robertson, and S. Christensen. 1987. Denitrification at different temporal and geographical scales: Proximal and distal controls. p. 174-192. In J. R. Wilson (ed.) Advances in nitrogen cycling in agricultural systems. CAB International, Wallingford, UK.

Jenkinson, D.S. 1988. Determination of microbial biomass carbon and nitrogen in soils. p. 368-386. In J.R. Wilson (ed.) Advances in nitrogen cycling in agricultural ecosystems. CAB International, Wallingford, UK.

Jordan, C. 1989. The effect of fertilizer type and application rate on denitrification losses from cut grassland in Northern Ireland. Fert. Res. 19:45-55. doi:10.1007/BF01080685

Lowrance, R., J.C. Johnson, G.L. Newton, and R.G. Williams. 1998. Denitrification from soils of a year-round forage production system fertilized with liquid dairy manure. J. Environ. Qual. 27:1504-1511. doi:10.2134/jeq1998.00472425002700060029x

Luo, J., R.W. Tilman, and P.R. Ball. 1999. Factors regulating denitrification in a soil under pasture. Soil Biol. Biochem. 31:913-927. doi:10.1016/ S0038-0717(99)00013-9

Mosier, A.R., W.D. Guenzi, and E.E. Schweizer. 1986. Field denitrification estimation by nitrogen-15 and acetylene inhibition techniques. Soil Sci. Soc. Am. J. 50:831-833. doi:10.2136/sssaj1986.03615995005000030052x

Parkin, T.B. 1987. Soil microsites as a source of denitrification variability. Soil Sci. Soc. Am. J. 51:1194-1199. doi:10.2136/ sssaj 1987.03615995005100050019x

Parsons, L.L., R.E. Murray, and M.S. Smith. 1991. Soil denitrification dynamics: Spatial and temporal variations of enzyme activity, populations and nitrogen gas loss. Soil Sci. Soc. Am. J. 55:90-95.

Ryden, J.C. 1983. Denitrification loss from a grassland soil in the field receiving different rates of nitrogen as ammonium nitrate. J. Soil Sci. 34:335-365.

Ryden, J.C., and L.J. Lund. 1980. Nature and extent of directly measured denitrification losses from some irrigated vegetable crop production units. Soil Sci. Soc. Am. J. 44:505-511. doi:10.2136/ sssaj1980.03615995004400030013x

Ryden, J.C., J.H. Skinner, and D.J. Nixon. 1987. Soil core incubation system for the field measurement of denitrification using acetylene-inhibition. Soil Biol. Biochem. 19:753-757. doi:10.1016/0038-0717(87)90059-9

Scott, N.A., R.L. Parfitt, D.J. Ross, and G.J. Salt. 1998. Carbon and nitro- gen transformations in New Zealand plantation forest soils from sites with different N status. Can. J. For. Res. 28:967-976. doi:10.1139/ cjfr-28-7-967

Schipper, L.A., A.J. Gold, and E.A. Davidson. 2010. Managing denitrification in human-dominated landscapes. Ecol. Eng. 36:1503-1506. doi:10.1016/j.ecoleng.2010.07.027

Schipper, L.A., and A. McGill. 2008. Nitrogen transformations in a denitrification layer irrigated with dairy factory effluent. Water Res. 42:24572464. doi:10.1016/j.watres.2008.01.033

Schipper, L.A., and M. Vojvodić-Vuković. 1998. Nitrate removal from groundwater using a denitrification wall amended with sawdust: Field trial. J. Environ. Qual. 27:664-668. doi:10.2134/ jeq1998.00472425002700030025x

Simek, M., L. Jisova, and D.W. Hopkins. 2002. What is the so called optimum $\mathrm{pH}$ for denitrification in soil? Soil Biol. Biochem. 34:1227-1234. doi:10.1016/S0038-0717(02)00059-7

Smith, M.S., and J.M. Tiedje. 1979. Phases of denitrification following oxygen depletion in soil. Soil Biol. Biochem. 11:261-267. doi:10.1016/0038-0717(79)90071-3

Sparling, G.P., L.A. Schipper, and J.M. Russell. 2001. Changes in soil properties after application of dairy factory effluent to New Zealand volcanic ash and pumice soils. Aust. J. Soil Res. 39:505-518. doi:10.1071/ SR00043

Sparling, G.P., and C. Zhu. 1993. Evaluation and calibration of methods to measure microbial biomass $\mathrm{C}$ and $\mathrm{N}$ in soils from Western Australia. Soil Biol. Biochem. 25:1793-1801. doi:10.1016/0038-0717(93)90185-E

Stevens, R.J., R.J. Laughlin, and J.P. Malone. 1998. Soil pH affects the process reducing nitrate to nitrous oxide and dinitrogen. Soil Biol. Biochem. 30:1119-1126. doi:10.1016/S0038-0717(97)00227-7

Tiedje, J.M. 1994. Denitrifiers. p. 245-267. In S.H. Mickelson (ed.) Methods of soil analysis Part 2. Microbiological and biochemical properties. SSSA Book Ser. 5. SSSA, Madison, WI.

Tiedje, J.M., S. Simkins, and P.M. Groffman. 1989. Perspectives on measurement of denitrification in the field including recommended protocols for acetylene based methods. Plant Soil 115:261-284. doi:10.1007/ BF02202594

van der Weerden, T., C. de Klein, and F. Kelliher. 2010. Influence of pore size distribution and soil water content on $\mathrm{N}_{2} \mathrm{O}$ response curves. In R.J. Gilkes and N. Prakongkep (ed.) Proceedings of the 19th International World Congress of Soil Science: Soil Solutions for a Changing World. Aug. 2010. Brisbane, Australia.

Wallenstein, M.D., D.D. Myrold, M. Firestone, and M. Voytek. 2006a. Environmental controls on denitrifying communities and denitrification rates: Insights from molecular methods. Ecol. Appl. 16:2143-2152. doi:10.1890/1051-0761(2006)016[2143:ECODCA]2.0.CO;2

Wallenstein, M.D., W.T. Peterjohn, and W.H. Schlesinger. 2006b. N fertilization effects on denitrification and $\mathrm{N}$ cycling in an aggrading forest. Ecol. Appl. 16:2168-2176. doi:10.1890/1051-0761(2006)016[2168:NFEO DA]2.0.CO;2

Wu, J., R.G. Joergensen, B. Pommeraning, R. Chaussod, and P.C. Brooks. 1990. Measurements of soil microbial biomass C by fumigation-extraction- an automated procedure. Soil Biol. Biochem. 22:1167-1169. doi:10.1016/0038-0717(90)90046-3 